\title{
Demographic Projection of the Tatar Nation, Living in Russia, with the Use of the Component Method
}

\author{
Gaisin R. I. ${ }^{1}$, Gaisin I. T. ${ }^{1}$, Biktimirov N. M. ${ }^{1}$, Vlasova E. I. ${ }^{1} \&$ Beketova S. I. ${ }^{1}$ \\ ${ }^{1}$ Kazan Federal University, Institute of Management, Economics and Finance, Kazan, Russia \\ Correspondence: Gaisin R. I., Kazan Federal University, Institute of Management, Economics and Finance, \\ Kazan, 420008, Russia.
}

Received: December 27, 2014 Accepted: February 19, 2015 Online Published: April 30, 2015

doi:10.5539/ass.v11n11p30 URL: http://dx.doi.org/10.5539/ass.v11n11p30

\begin{abstract}
This study is devoted to the topic generated features of modern economic development of market relations.

On the Tatar population of Russia were still prepared a number of historical and demographic research, but future studies of demographic processes for the foreseeable future absent.

This article was prepared by the demographic forecast of the Tatar nation living in Russia in 2025 by federal districts and regions of the country using the method of components.

In formulating this prediction were applied several well-known methods of forecasting population. In the article used census data and statistical compilations.
\end{abstract}

Keywords: Tatar nation, demographic projection, component method

\section{Introduction}

Throughout the recent history, Russia is experiencing a truly dramatic in its nature process. In this period thorny and contradictory problems showed up in all spheres of public life, including unresolved ethnic problems, a significant change in geo-demographic situation, the problems associated with migration, etc. That is why today there is an urgent need for a comprehensive research of demographic indicators all along the regions, taking into account the peculiarities of ethno-demographic trends identified for use in the development and refinement of the general demographic population projections.

However, knowledge of the ethnic dimensions of geo-demographic development is a fairly complicated study because of their inconsistency and ambiguity. For Russia, this situation is complicated by its significant regional and ethnic differentiation as well as the fact that many aspects of the demographic development remained outside scientists' sight. Therefore, this issue needs to be addressed through new research that could explain scientifically modern geo-demographic process and considering the ethnic aspect to formulate new adequate judgment.

\section{Methodology}

Systematic structural analysis, mathematical statistics, comparative analytical and the method of the component were used as methods for writing an article.

\section{The Main Part}

During the development of demographic processes forecasts for the future, mathematical models are widely used to account effect of time-varying socioeconomic factors on the demographic phenomena. However, such models are most effective only during periods of uniform development of demographic processes, without jumps and sharp frames.

Currently, the dynamics of the population in the Russian Federation exposed to significant and hardly predictable changes. As a result, more reasonable is an application in order to predict the demographic the method of the component.

Double name of the demographic projection method (the method of the component, or method of advancing age) due to the fact that, firstly, its application is based on the use of demographic balance equation:

$$
\mathrm{P}_{1} \quad \mathrm{P}_{0}+\mathrm{B}-\mathrm{D}+\mathrm{M}_{\mathrm{i}}-\mathrm{M}_{0},
$$


where $P_{o}$ and $P_{1}$ - the population at the beginning and end of the period (year); $\mathrm{B}$ - the number of births for the period; D - the number of deaths for the period; $M_{i}$ - influx of migrants during the period; $M_{0}$ - out-migration during the period. In this case, B, D, $M_{i}$ and $M_{0}$ are named the components of population change for the period (year).

Secondly, the fact that data on the number of individual age-sex groups are moved each year into the next age, and the number of zero-age group is determined based on the forecast of the annual number of births and infant mortality. As is well known, the essence of the method of component is to "track" the motion of individual cohorts over time in accordance with predetermined (forward-looking) parameters of fertility, mortality and migration. If these parameters are fixed at some initial time $t_{0}$, and then remain constant throughout the period $\Delta_{\mathrm{t}}$, it allows you to define the size and structure of the population at time $t_{0}+\Delta_{\mathrm{t}}$.

Starting at time $t_{0}$, the population of each age is reduced in accordance with the estimated age-specific probabilities of death. From the initial population of each age subtracted the number of dead and the survivors are a year older. Predicted age-specific fertility rates are used to determine the number of births for each year of the forecast period. Newborns are also beginning to feel the risk of death in accordance with generally accepted levels of mortality. The method of the component also takes into account the value of the component age-specific migration rate (arrival and departure).

For a better understanding of this process technology demographic projections give a perspective calculation on the example of one-year age intervals for the female population.

Suppose that at some initial time $\mathrm{t}_{0}$ (the base year of the projection-2002) female population at age $x$ is $P_{x}^{0}$. During the year, the number of initial change: is one part of the population dies, the other part of the population leave the territory, somebody on the contrary will arrive at the residence. As a result, the population ages $(\mathrm{x}+1)$ at time $\mathrm{t}_{1}$ are equal to:

$$
\mathrm{P}_{\mathrm{x}+1}^{1}=\mathrm{P}_{\mathrm{x}}{ }^{0}-\mathrm{S}_{\mathrm{x}}+\mathrm{M}_{\mathrm{x}}^{\mathrm{s}}
$$

where $S_{x}=\frac{L_{x+1}}{L_{x}}$ - ratio of advancing to the next age. $\left(L_{x}\right.$ и $\mathrm{L}_{x+1}-$ the number of people living in ages $\mathrm{x}$ and $\mathrm{x}$ +1 of mortality tables), $\mathrm{M}_{x}^{s}$ - balance of age-specific migration.

The same procedure applies to all ages except age 0 years.

The above procedure is iteratively repeated as many times as the forecast period covers the years. The population of each age as it moves into the next higher age. That is why the method of the component is also called the "method of advancing age."

Intuitively, this can be represented as follows (Figure 1).

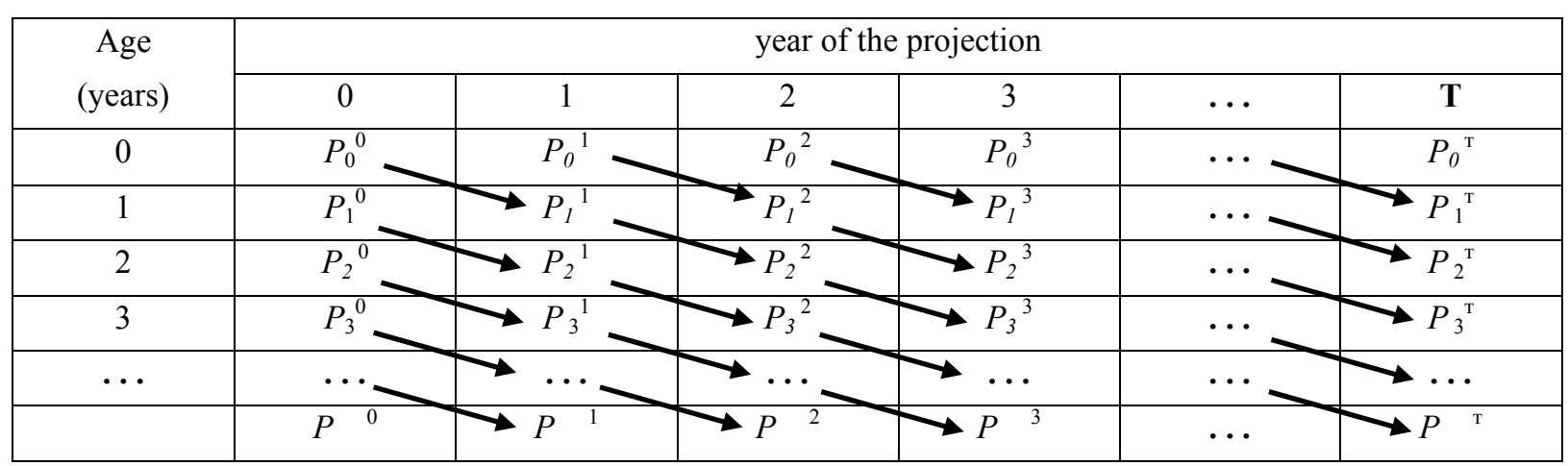

Figure 1. Demographic projection scheme using advancing age

As the object of the prediction method of the component was chosen Tatar population, which lives in the Russian Federation. Predictive estimate population of Tatars in 2025 held at the territorial level, at the level of federal districts and the individual subjects of the country.

As an object for the prediction of the Tatar population was not chosen randomly. This is due to several reasons: firstly, the Tatars - the second largest nation within the Russian Federation. The Tatars part of the total population of Russia in the 2010 census was (3.7\%). Secondly, the Tatars have a deep history and millennial 
cultural traditions, including writing, and relate to the whole of Eurasia. Third, in many ethno-demographic parameters in decades Tatars have been impressive evolution.

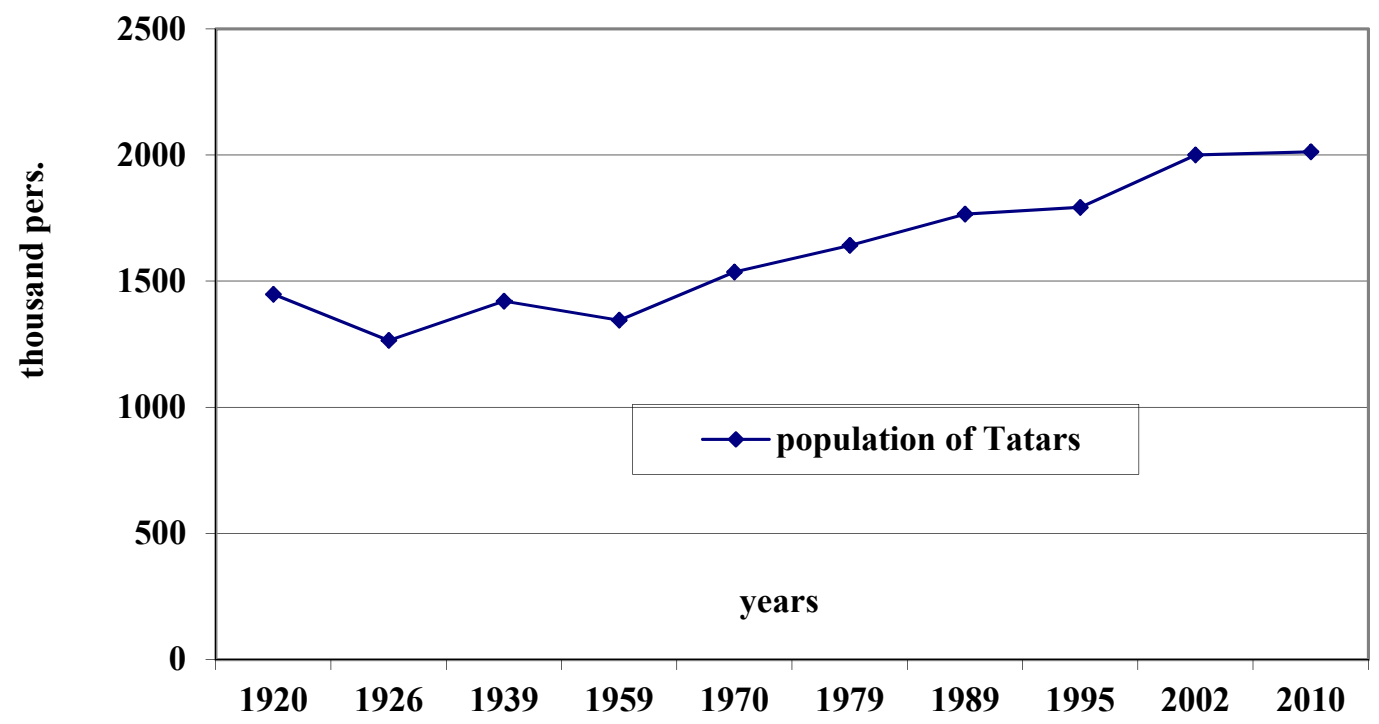

Figure 2. Dynamics of population of Tatars in Tatarstan (in thousand Pers.)

\section{Conclusions}

1. According to the forecast, developed by using the method of advancing age, the population of Tatars living in Russia in 2025 will amount to about 5 million 67 thousand pers., almost 500 thousand less than the population of Tatars in the country for the 2002 census (5554.6 thousand pers.) and 244 thousand less than in the 2010 census.

2. Population projection Tatars in 2025 in Russia showed that there are significant regional differences in the change in these indicators by regions of the country. Of the seven federal districts only three are expected to increase the number of Tatars - Volga (209.5 thousand pers.), Central (25.2 thousand pers.), South (14.4 thousand pers.). In other districts the number and proportion of Tatars will steadily decrease;

In the Far Eastern Federal District Tatars population at the end of the forecast period may be reduced by ten times. From other districts the maximum reduction is expected in the Arkhangelsk and Murmansk regions, in the Republic of Tyva. In general, the maximum negative dynamics of the population of the Tatars in 2025 observed with increasing distance from the Republic of Tatarstan to the east and north-east;

3. Dispersed settlement of Tatars living on the territory of Russia and abroad, will be gradually replaced by localization, concentration in the core areas in the Volga-Urals region. Core of their territorial concentration will coincide with the boundaries of the Republic of Tatarstan and Bashkortostan. In the Volga-Ural region is projected to return migration of many of those who went before in the northern and eastern parts of the country;

4. Win Tatars in Bashkortostan, the second largest outbreak of their concentration, according to the latest census of the population is continuously decreasing. If the features of this trend of development of the entire population as a basis and to recognize the validity of the results of the past census, by 2025 the population of Tatars living in Bashkortostan can be significantly reduced (for 2010-2025 170 thousand.). Nevertheless, the Republic of Bashkortostan will be the second center of concentration of the Tatars in the multi-ethnic country and the second largest after the Republic of Tatarstan area of settlement of the Tatar nation. According to forecast data in Bashkortostan in 2025 will live about 760 thousand Tatars (13.6\% of the Tatars of the Russian Federation);

5. In many western regions of the Russian Federation is expected a slight increase in the Tatar population, and in some subjects - rapidly. In all regions of the Central Black Earth economic region expected high (Tambov region. $(130 \%))$ and very high (Belgorod (200\%), Voronezh (180\%), Lipetsk (180\%), Kursk (160\%)) percentage of population change representatives of the Tatar nation. This is explained by the significant migration potential of Eastern Europe and the deterioration of the geopolitical situation in Ukraine. The total number of Tatars of the citizens of these countries is a significant amount: in the Ukraine - 140.0 thousand, Belarus - 13.5 thousand, 
Moldova - 4.0 thousand, Romania - 23.0 thousand, Poland - 6, 0 thousand, Bulgaria - 5.0 thousand, Latvia - 6.0 thousand etc. It is from these countries, there is return migration of Tatars in Central Black Earth region;

6. Tatars urbanization will continue to occur rapidly, with their places of permanent settlement will increasingly serve larger cities and agglomerations. Projected significant growth in population of Tatars in most major cities and regions with a relatively high standard of living.

7. Taking place in the Russian migration will actively influence the formation of the national composition of the population. Until recently, the largest influx of people of Tatar nationality caused by the deterioration of the geopolitical situation occurred in recent years from Uzbekistan and Kazakhstan. However, this migration flow in the future will only be reduced. The share of other CIS countries in a positive migration balance of the Tatar population has always been small. However, this migration flow in the future will only be reduced. The share of other CIS countries in a positive migration balance of the Tatar population has always been small. Therefore, in what is expected to increase the importance of migration in other countries, mainly in the west and south-west of the CIS and Baltic countries as well as Central and Eastern Europe.

8. Development of culture and education rose dramatically changed the face of the Tatar nation, erasing many of the local regional characteristics and ethnic identity. Ethno evolution of the demographic behavior of the majority of Tatars and other peoples of the country, apparently, is irreversible and can lead to the formation processes ethnotransformational unified Russian ethnos.

In our opinion, the exception of the column "nationality" of the main statistical tables and official documents will result in the loss of national identity and diversity of Russia.

\section{References}

Basovskii, L. E. (1999). Forecasting and planning in market conditions (p. 260). Textbook. INFRA-M.

Demographic Yearbook of Russia (p. 595). (2005). The Stat.sb. / Rosstat.

Denmukhametov, R. R., \& Zjablova, O. V. (n. d.). Geodemographic Situation in the Republic of Tatarstan. World Applied Sciences Journal, 30(11), 1684-1688.

Dulaeva, R. A. (2002). Tatars on the planet Earth (p. 155). Kazan: in "Printing House".

Gaisin, I. T., \& Biktimirov, N. M. (n. d.). Migration Processes in the Republic Tatarstan in the Second Half of the 20th and in the Early of 21st Centuries: Ethnic and Social Aspects. Middle-East Journal of Scientific, 20(12), 1761-1766.

Informational materials about the final outcome the National Population Census. (2010).

Ishakov, D. M. (2005). The 2002 census in Bashkortostan: historical and demographic comment on the results (p. 60). Kazan: Ethnic Monitoring Centre.

Lugachev, M. I., \& Lyapuntsov, Y. P. (1999). Methods of social and economic forecasting. Economics Faculty of Moscow State University, TEIS.

Mardzhani, S. (2006). Tatar nation in the XXI century: problems of development (p. 456). Kazan Institute of History named. Tatarstan Academy of Sciences.

National composition and language skills, citizenship. (2004). IPC "Statistics of Russia" (p. 946). (The results of the census of 2002: At 14 v., Federal State Statistics Service, Volume 4, Book 1).

Orlov, I. V. (2000). Economic-mathematical methods and models. Performing calculations in Excel (p. 136). JSC "Finstatinform".

Results of the All-Union census of 1989. (1990). Volume 2 National composition of the population of the Tatar ASSR (p. 272). Kazan: Tatstatupravlenie.

The main results of the National Census of 2002. (2005). IPC "Statistics of Russia" (p. 493). (The results of the National Population Census 2002: In 14 volumes, Feder.sluzhba state. Statistics; Volume 14).

\section{Copyrights}

Copyright for this article is retained by the author(s), with first publication rights granted to the journal.

This is an open-access article distributed under the terms and conditions of the Creative Commons Attribution license (http://creativecommons.org/licenses/by/3.0/). 